\title{
EXPORT GROWTH OF NAFTA MEMBERS, INTRA- INDUSTRY TRADE AND ADJUSTMENT
}

\author{
Marius Brïlhart \\ University of Lausanne, Switzerland \\ Michael Thorpe \\ Curtin University of Technology, Western Australia \\ paper published in Global Business and Economics Review, vol. \\ 3, no. 1, pp. 94-110, June 2001
}




\begin{abstract}
This paper looks at the issue of labour market adjustment in the context of expanded international trade of NAFTA economies both within the region and more generally. The study focuses on the period 1990-1998, a time-frame which covers several years prior to and after the formation of NAFTA.

Trade flows of the member countries are analysed using measures of static intra-industry trade (IIT) and dynamic (marginal) intra-industry trade (MIIT).Inferences are drawn from these results on the basis of the 'smooth adjustment hypothesis' according to which IIT entails relatively low factormarket adjustment costs. The paper concludes that for trade flows within NAFTA, less labour market adjustment pressures are being exp erienced by the US and Mexico in terms of their relationship. A similar observation can be made for US-Canada trade. Trade between Canada and Mexico is seen as causing relatively more adjustment pressure compared to other intra-regional flows. In terms of the trade of NAFTA embers with major trading partners outside of the group, the results are mixed.
\end{abstract}




\section{INTRODUCTION}

The North American Free Trade Agreement (NAFTA)1, is now seven years old. Since the mid-1990's there has been significant growth in NAFTA's intra-regional trade as well as in the trade of member countries more generally with the rest of the world. In some areas these developments have raised anxieties about jobs being lost "overseas" to low-wage competitors. In the case of NAFTA, the fear is one of US and Canadian industries shifting to Mexico, together with a decline in domestic industries as they face growing import competition (Cremeans, 1999). More generally, the impact of trade expansion per se has been widely debated as to its contribution to the observed decline in relative wage levels of lower skilled workers and job losses in many traditional industries in both the US and Canada (Scheve and Slaughter, 2001; Slaughter and Swagel, 1997). Even economists who accept that international specialisation along comparative advantage lines is a positive-sum game have to acknowledge that changes in specialisation entail at least transitional adjustment costs and produce losers as well as gainers. Blue-collar workers in industrialised countries are often identified as the main losers from the expansion in international trade. In contrast to populist rhetoric, a majority of empirical analyses have found that trade liberalisation accounts for some of the fall in demand for blue-collar workers in developed countries, but that the contribution of trade is small and by far the bigger culprit is trade-independent technological change (for a survey, see Freeman, 1995; Krugman, 1995). However, a re-assessment of the trade-employment link in the 1990s, which accounts for different production technologies across countries, has led to an upward revision of the consensus estimate of trade effects (see Wood, 1994). It must be noted, that the emerging empirical consensus about the significance of trade liberalis ation for US and EU labour-market adjustment is superseded by even stronger normative agreement that a return to protectionism would be detrimental (see Wood, 1995; and Sachs and Shatz, 1996).

The adjustment implications of trade expansion for NAFTA members are clearly important, especially as the debate regarding the benefits or otherwise of a liberal global trading regime gathers force around the world. One widely used empirical method to assess the adjustment implications of trade expansion is to analyse patterns of intra-industry trade (IIT). A popular and intuitively appealing hypothesis states that a high share of IIT will be associated with relatively low labour-market disruption. With intra-industry adjustment, workers move within industries rather than between them, which is likely to entail lower adjustment costs.

Two developments of the IIT literature in the 1990s have cast a degree of doubt over the standard hypothesis that high and growing IIT is associated with low adjustment costs. One development was the analysis of trade flows in terms of product quality, inferred from unit values. A distinction between vertical and horizontal IIT was proposed, where the former relates to twoway trade in goods of different quality and the latter stands for two-way 
trade in goods of similar quality (Greenaway, Hines and Milner, 1994). Empirical studies found that the bulk of IIT is in vertically differentiated goods, hence adjustment pressures with IIT might be larger than conventionally assumed (see, e.g., Fontagné, Freudenberg and Peridy, 1997). A second recent development in the analysis of IIT was more immediately concerned with the issue of adjustment. Hamilton and Kniest (1991) have argued that traditional static measures of IIT are not inherently related to changes in trade and specialisation. Adjustment arises in production changes over time, and is therefore a dynamic phenomenon. Addressing this shortcoming of the traditional IIT index, alternative measures of marginal IIT (MIIT) were developed, and there is growing evidence that these measures relate to adjustment much more directly than the static indices (see Brülhart, 2000).

This paper analyses the evolution of trade patterns of NAFTA members, focusing on the period 1990-1998. This encompasses both pre and postNAFTA trade experiences. The patterns of IIT and implications for adjustment are assessed. In Section 2, we review the intellectual background to the IIT-adjustment hypothesis, with particular emphasis on MIIT. Section 3 provides a descriptive summary of trade developments in the US, Canada and Mexico, as well as detail and discussion of patterns of IIT and MIIT.

\section{INTRA-INDUSTRY TRADE AND ADJUSTMENT: CONCEPTS AND THEORY}

\section{The Hypothesis of IIT and Smooth Adjustment}

The proposition that IIT entails lower costs of factor-market adjustment than inter-industry trade, originally made by Balassa (1966), has become widely accepted in international economics. However, this much-quoted hypothesis has been subjected to little formal scrutiny, both in the theoretical and in the empirical literature.

One consequence of the lack of formal analysis is that the precise meaning of the IIT-adjustment hypothesis has been stated only in loose terms, and the two variables, trade-induced adjustment costs and IIT, have been subject to differing implicit interpretations.

We therefore briefly elucidate the key components: trade as an exogenous variable, adjustment costs and IIT.

There are two conceptions of trade as a source of adjustment. In partialequilibrium, small open economy (SOE) models adjustment is traditionally analysed by departing from a change in world market prices. Such price changes are exogenous to the SOE, and can originate in a multitude of sources, such as changes in demand, factor endowments or trade policies of trading partners. These changes can be labelled "trade-induced", since they would not affect the SOE in autarky. The second concept of trade as a source of adjustment centres on changes in these trade costs, holding everything else constant in multi-country general-equilibrium models. Under that definition, "trade-induced" means sparked by a change in the level of barriers to international trade. In a nutshell, domestic adjustment is trade- 
induced either if caused by a reduction in trade barriers, holding everything else constant; or if caused by any relevant changes in foreign markets, holding trade costs constant (i.e. zero).2

Adjustment costs can also be grouped into two categories. First, they can arise in perfectly competitive narkets with flexible prices. If factors are subject to any degree of heterogeneity and product specificity, then tradeinduced re-allocation will inevitably divert resources to make the transition possible. Hence, production will occur inside the long-run production possibility frontier for the duration of adjustment, as resources are used to re-train, move and match labour, and to adapt the capital stock. Temporary factor-price disparities are needed to incite resource use on such "adjustment services". When arising from a fall in the relative price of importables (e.g. through integration), adjustment costs of this nature do not lead to an aggregate welfare loss, and their impact is purely distributional.3 In theory, lump-sum transfers can be designed so a to compensate all individuals for transitional income losses.4 In practice, however, transitional wage and income disparities often go uncompensated, thus producing net losers and feeding protectionist pressures.

The second class of adjustment costs arises in the presence of market imperfections. The most commonly analysed imperfection is that of downwardly rigid nominal wages. Under such a configuration, adjustment costs can outweigh the gains from trade, hence trade liberalisation might be Pareto inferior.5 The cost-benefit balance depends on the magnitude of adjustment costs and trade gains as well as on the social discount rate.

The standard measure of IIT is the Grubel-Lloyd (GL) index:

$$
G L_{t}=\left(1-\frac{|M-X|}{(M+X)}\right)_{t}
$$

where $M$ stands for imports in a particular industry, $X$ represents corresponding exports and $t$ is the reference year. The value of this index ranges between 0 and 1 , inclusive. The former value indicates that all trade is of the inter-industry type, the latter that all trade is IIT. It has become standard practice not to adjust the index for overall trade imbalance, since an unbalanced trade account can well be compatible with overall balance of payments equilibrium. A survey of this and related issues with relevance to the interpretation of GL indices can be found in Greenaway and Milner (1986). The GL coefficient leaves room for at least two interpretations of IIT in the adjustment context. IIT could refer to either the GL index at the start or end of the relevant period $(G L t)$, or to the growth of the GL index over that period (? GL).

The GL index is a static measure, in the sense that it captures IIT for one particular year. However, adjustment is a dynamic phenomenon. By suggesting the concept of marginal IIT (MIIT), Hamilton and Kniest (1991) have opened a dimension to the empirical study of IIT which acknowledged this problem and endeavoured to define IIT in a sense that is compatible with the smooth-adjustment hypothesis. They argued that the observation of a high proportion of IIT in one particular time period does not justify a priori 
any prediction of the likely pattern of change in trade flows. Even an observed increase in static IIT levels between two periods (positive $\Delta G L$ ) could "hide" a very uneven change in trade flows, concomitant with interrather than intra-industry adjustment.

Brülhart (1994) has suggested the following index to measure MIIT:6

$$
A=1-\frac{|\Delta X-\Delta M|}{|\Delta X|+|\Delta M|}
$$

where ? stands for the difference between years $t$ and $t-n$. This index, like the GL coefficient, varies between 0 and 1 , where 0 indicates marginal trade in the particular industry to be completely of the inter-industry type, and 1 represents marginal trade to be entirely of the intra-industry type. The index $A$ shares most of the statistical properties of the GL index.7

\section{Theoretical Underpinnings}

Adjustment affects all production factors. The analysis of IIT has been implicitly concerned with adjustment in the labour market. The most accessible theoretical framework for a discussion of adjustment issues is the specific-factors model, which was expounded concisely by Neary (1985). This model assumes a small open economy which produces and consumes an exportable and an importable good facing perfect competition in all markets and given world prices. Labour can move between the two sectors (but not between countries), all other factors are fixed (the "specific" factors), and there are diminishing returns to factor inputs. Imagine an export boom, which is equivalent to a fall in the relative demand for importables, triggered by some measure of trade liberalisation. If adjustment were perfectly smooth, the economy would instantly attain a new equilibrium where the unique economy-wide wage in terms of the exportable has fallen, and some workers have switched employment from the contracting import sector to the expanding export sector. In reality, this transition is likely to be costly. As discussed above, these costs can take the form of "adjustment services" to adapt labour and/or of temporary unemployment in the presence of sticky wages.

We can formulate the IIT-adjustment hypothesis in terms of the specificfactors model. According to the IIT literature, adjustment is smoother in terms of "adjustment services" and unemployment if the expanding and contracting activities are contained within the same industry, than if they represent two different industries. This hypothesis implicitly makes at least one of the following two assumptions:

- the adaptability of labour is greater within industries than between industries, ceteris paribus, or

- relative wages are more flexible within industries than between industries, ceteris paribus. 
The first justification for the expectation of smooth intra-industry adjustment has great intuitive appeal. If we define IIT as the exchange of goods with similar production requirements, it is implied that labour requirements are more similar within than between industries. If the skills acquired by the workers and managers of a contracting firm can be applied without much re-training in an expanding firm of the same industry, then labour mobility may well be higher within industries than between them. Where IIT reflects intra-firm trade, workers can simply be transferred from one department to another.

The second hypothesis seems less plausible. The main impediments to wage flexibility are minimum-wage legislation and contractual wage agreements at the industry level. Since such constraints generally apply at the level of the entire economy or of individual industries, they might actually be expected to allow greater wage flexibility between industries than within them. If temporary wage inflexibility through industry-wide centralised bargaining is the dominant cause of adjustment problems, then adjustment costs would be greater when trade shocks are intra-industry than when trade alters the relative positions between industries.

Ultimately, the homogeneity and adaptability of industries, as defined in trade statistics, can only be determined through empirical investigation. Due to the difficulty of obtaining appropriate data, the smooth-adjustment hypothesis has been subjected to few empirical tests. There is increasing evidence, however, that MIIT, but not IIT in the static sense, relates negatively to adjustment costs (see Brülhart and Hine, 1998; Brülhart, 2000)

\section{TRADE PATTERNS OF NAFTA MEMBERS}

\section{Trade Growth 1990-98}

On the whole, the 1990's has been a period of strong economic growth in all NAFTA member countries, notwithstanding the slump in Mexico's performance in 1995 (Table 1). During this time growth of total trade with the rest of the world of all countries has been consistently high, resulting in increased openness (Tables 2, 3). As a share of GDP, the deficit on the US balance of goods trade has increased, while Canada has tended towards a relatively stable surplus. Mexico has moved towards surplus in its balance on goods trade in the period since joining NAFTA in the mid-1990's. Tables 4 and 5 provide evidence of the important role that intra-NAFTA trade has played in the overall position of member countries' trade balances. The US remains Canada's and Mexico's biggest trade partner, while Canada and Mexico are the largest and second largest trading partners, respectively, of the US. Trade with Mexico and Canada comprises around 40 per cent of US trade in goods with the world. Since the inception of NAFTA in 1994, trade between the US, Canada and Mexico has almost doubled. US trade with Mexico increased 113 per cent over 1994-1998, while that with Canada increased 56 per cent. Imports to the US from its partners in NAFTA have grown at a faster rate than exports (Table 5). US exports to Mexico surpass exports to Japan, an economy over ten times the size of Mexico. Meanwhile Canada's trade with Mexico, although modest in absolute terms compared to 
US-Mexico trade, has doubled over the period (Lustig, 2001). Canada is the second most important export market for Mexico, and Mexico has become Canada's third most important market.

Table 1

NAFTA Economic Growth

(Real GDP growth, percent per annum)

$\begin{array}{lccc} & \text { UNITED } & \text { CANADA } & \text { MEXICO } \\ \text { STATES } & 1.2 & 0.3 & 5.2 \\ 1990 & -0.9 & -1.9 & 4.2 \\ 1991 & 2.7 & 0.9 & 3.5 \\ 1992 & 2.3 & 2.5 & 1.9 \\ 1993 & 3.5 & 4.7 & 4.5 \\ 1994 & 2.3 & 2.6 & -6.2 \\ 1995 & 3.3 & 1.2 & 5.2 \\ 1996 & 3.9 & 3.8 & 7.0 \\ 1997 & 3.9 & 3.1 & 4.7 \\ 1998 & & & \end{array}$

Source: World Bank (World Development Report, various years)

Table 2

NAFTA Merchandise Trade Growth With All Partners

(Percent per annum)*

UNITED STATES
EXPORTS IMPORTS

CANADA
EEXICO
EXPORTS IMPORTS EXPORTS

IMPORTS

1990

$8.5 \quad 3.9$

$$
4.7
$$

2.3

3.2

6.2

5.3

5.1

1.7

1991

1992

6.6

-5
7.5

2.3
7.9

5.0

15.2

1993

2.9

8.9

12.0

8.1

8.2

12.2

13.1

8.3

8.1

11.3

8.8

8.8

17.8

21.3

1996

1997

9.3

6.4

13.9

13.3

18.2

22.0

1998

10.8

5.3

13.0

4.9

* Constant Prices

Source: World Bank (World Development Report, various years) 
Table 3

Importance of NAFTA Goods Trade With All Partners

(Trade as percent of GDP)

$\begin{array}{lcccccc}\text { United } & \mathbf{1 9 9 3} & \mathbf{1 9 9 4} & \mathbf{1 9 9 5} & \mathbf{1 9 9 6} & \mathbf{1 9 9 7} & \mathbf{1 9 9 8} \\ \text { States } & & & & & & \\ \text { Exports } & 7.2 & 7.7 & 8.4 & 8.9 & 9.9 & 9.8 \\ \text { Imports } & 9.4 & 10.3 & 11.0 & 11.7 & 13.0 & 14.0 \\ \text { Balance } & -2.2 & -2.6 & -2.6 & -2.8 & -3.0 & -4.2 \\ \text { Canada } & & & & & & \\ \text { Exports } & 25.4 & 27.5 & 29.2 & 30.5 & 32.0 & 33.5 \\ \text { Imports } & 23.4 & 24.8 & 25.9 & 27.0 & 30.3 & 31.0 \\ \text { Balance } & 2.0 & 2.7 & 3.5 & 2.5 & 1.7 & 2.5 \\ \text { Mexico } & & & & & & \\ \text { Exports } & 15.2 & 17.1 & 23.8 & 26.8 & 28.3 & 30.0 \\ \text { Imports } & 19.1 & 22.2 & 20.1 & 23.5 & 26.8 & 30.2 \\ \text { Balance } & -3.9 & -5.1 & 3.7 & 3.3 & 1.5 & -0.2\end{array}$

Source: World Bank Trade Statistics

The US deficit within NAFTA on goods trade has more than tripled over the last five years.8 Critics in the US point to this growing deficit, as evidenced in Table 6, as a cause for concern (Scheve and Slaughter, 2001). However imports provide key inputs to production and satisfy consumer demand. Gonzalez and Velez (1995) have noted that trade between Mexico and the US has been characterised by significant levels of assembly and other value-added activities of US components in Mexico for re-export to the US. The top twenty imports and exports traded between the US and Mexico have tended to be in virtually the same industries, implying complementary products (Wientraub, 1997). It is suggested that this allows North American industries to specialise and develop economies of scale for increased productivity and competitiveness.

The US International Trade Commission (1997) notes that the rapid growth in Mexican manufactured exports to the US has been accompanied by a closely related growth in US exports of intermediate inputs in similar industries. It has also been observed that American imports from Mexico have much higher US content than imports from other markets. Mexican imports are closely linked to exports. Such trade outcomes seem to provide good examples of vertical IIT in the sense of Lloyd (1998), where semi-processed goods are exported, only to be re-imported at a higher stage of processing. Proportionally, the largest post-NAFTA import surges into the US from Mexico have been in textiles and paper products and these account for less than one per cent of all US manufacturing imports. The next highest import growth has been in those sectors which also had high increases in sales from the US to Mexico, namely transportation (the automotive sector) and machinery (electronics and computers). Burfisher, Robinson and Thierfelder (2001) provide evidence that shows that both the textile and apparel and auto industries in the US and Mexico have become more closely integrated since 
the formation of NAFTA. Efficiency gains have been obtained from a widening of markets and increasing returns from finer specialisation within industries

Table 4

Trade Shares by Major Trading Partners*

(Percent of total trade)

$\begin{array}{lcccc}\text { US } & \mathbf{1 9 8 0} & \mathbf{1 9 8 5} & \mathbf{1 9 9 0} & \mathbf{1 9 9 8} \\ \text { Canada } & 13 & 22 & 20 & 26 \\ \text { Mexico } & 5 & 7 & 7 & 13 \\ \text { EU } & 10 & 17 & 17 & 17 \\ \text { Japan } & 4 & 11 & 15 & 10 \\ \text { CANADA } & & & & \\ \text { US } & 64 & 71 & 71 & 53 \\ \text { Mexico } & 1 & 2 & 1 & 2 \\ \text { EU } & 8 & 15 & 14 & 8 \\ \text { Japan } & 3 & 7 & 5 & 3 \\ \text { MEXICO } & & & & \\ \text { US } & 60 & 72 & 76 & 2 \\ \text { Canada } & 2 & 2 & 1 & 8 \\ \text { EU } & 11 & 10 & 14 & 4 \\ \text { Japan } & 3 & 5 & 4 & \end{array}$

* EU here refers to the group of 12 members

Source: World Bank Trade Statistics

Table 5

Growth in Bilateral Goods Trade (Before and After NAFTA)

(Percent Per Annum)

$\begin{array}{lcc} & \mathbf{1 9 8 9 - 1 9 9 3} & \mathbf{1 9 9 3 - 1 9 9 7} \\ \text { US exports to Canada } & 6.3 & 10.6 \\ \text { Canadian exports to US } & 6.0 & 10.9 \\ \text { US exports to Mexico } & 13.6 & 14.5 \\ \text { Mexican exports to US } & 10.1 & 21.1 \\ \text { Canadian exports to } & 4.3 & 9.2 \\ \text { Mexico } & & \\ \text { Mexican exports to } & 18.8 & 15.1 \\ \text { Canada } & & \end{array}$

Source: Cremeans (1999) 
Table 6

NAFTA Trade Balances

(Million Dollars US)

$\begin{array}{cccc} & \text { UNITED STATES } & \text { CANADA } & \text { MEXICO } \\ 1989 & -11324 & 8225 & 3099 \\ 1990 & -9584 & 6759 & 2825 \\ 1991 & -3767 & 4155 & -388 \\ 1992 & -2655 & 6404 & -3749 \\ 1993 & -9108 & 8515 & 593 \\ 1994 & -12617 & 11427 & 1190 \\ 1995 & -33516 & 15034 & 18482 \\ 1996 & -40124 & 20390 & 19734 \\ 1997 & -32378 & 13578 & 18620 \\ 1998 & -33378 & - & -\end{array}$

Source: Cremeans (1999)

Strong growth has been seen since 1990 in Canada-US bilateral IIT across a number of industries, including processed food products, chemicals and clothing (Hunter, 1998). This is seen as indicating increased IIT specialisation, linked to expanded investment flows between the partners.

Recent reports that indicate that many Canadians as well as Americans consider that a more liberal trade regime, both generally and in the context of NAFTA, has not been beneficial in terms of employment and also declining wages (Scheve and Slaughter, 2000; Cremeans, 1999). Econometric evidence, however, tends to suggest that the employment effects of NAFTA have been negligible for the US, taken in the context of the enormous job creation over the past six years (Burfisher et al., 2001). Krugman (1995) and Slaughter and Swagel (1997) highlight the relative importance of technological change and productivity, as opposed to trade, as agents of change in labour markets. McClenahen (2000) argues that automation and productivity gains have been primarily responsible for observed labour displacement in the US clothing and apparel industry, while Burfisher et al (2001) indicate that NAFTA has, in fact, helped employment within areas of the auto sector. Overestimation of import job displacement has been attributed to a poor understanding of the extent of complementarity of US-Mexico production and trade, a feature which began to emerge even prior to the NAFTA agreement (Ojeda et al, 1996).

As part of the terms of NAFTA there is opportunity for US workers to seek training and assistance if it can be shown that jobs were lost or jeopardised as a result of the agreement. Crimeans (1999) reports that this assistance program records that over the period January 1994 to August 1998 overall US employment increased by 565,000 in manufacturing while gross job losses were around 179,000. It is considered that the net impact of NAFTA trade, once allowance is made for the gains in employment which have ensued, has been relatively small for labour in the US manufacturing sector. 


\section{Intra-Industry Trade}

Recent trade developments within NAFTA are viewed in some quarters as contributing significantly to the strong pressures for adjustment which are seen in the domestic economies of member countries. As noted in the previous section, however, there is evidence that other influences are at work. To the extent that trade expansion has been (M)IIT in nature it would lend support to the argument that the pressures for factor market adjustments from this source would be less.

Table 7 reports the summary GL indices for NAFTA members. These indices are calculated from SITC three-digit trade data. Three digit sectors correspond to the standard definition of "industry" in the IIT literature (see Greenaway and Milner, 1986). The results document a consistent upward trend in IIT in each country. Between 1980 and 1998, the aggregate GL index for manufacturing products (SITC 5-8) grew from 0.36 to 0.66 in Mexico, from 0.61 to 0.72 in Canada and from 0.62 to 0.70 in the US. The sectoral composition of imports and exports has therefore become more similar over time in all these countries, with Mexico exhibiting a dramatic shift in its trade make-up.

Table 7

Total Intra-Industry Trade, 1980-98

(Unadjusted Grubel-Lloyd indices, 3-digit SITC level)

\begin{tabular}{lcccccccc} 
& \multicolumn{2}{c}{1980} & \multicolumn{2}{c}{1990} & \multicolumn{2}{c}{1995} & \multicolumn{2}{c}{1998} \\
SITC & $\mathbf{0 - 8}$ & $\mathbf{5 - 8}$ & $\mathbf{0 - 8}$ & $\mathbf{5 - 8}$ & $\mathbf{0 - 8}$ & $\mathbf{5 - 8}$ & $\mathbf{0 - 8}$ & $\mathbf{5 - 8}$ \\
US & 0.45 & 0.62 & 0.51 & 0.60 & 0.62 & 0.69 & 0.66 & 0.70 \\
Canada & 0.53 & 0.61 & 0.63 & 0.71 & 0,64 & 0.69 & 0.67 & 0.72 \\
Mexico & 0.27 & 0.36 & 0.32 & 0.54 & 0.44 & 0.56 & 0.61 & 0.66
\end{tabular}

Source: United Nations Trade Data, International Economic Data Base,

Australian National University; authors' own calculations

In Table 8 GL indices are reported separately for each member with its major trading partners, other NAFTA members, the European Union (EU) and Japan. We find that a generally rising trend in IIT is evident for the US in trade relations with each of the major groups of partners. In particular trade with Mexico is seen to have undergone a significant shift in terms of the extent of its two-way trade with the US. This is in accord with some of the evidence outlined earlier. Trade with Japan reflects the fact that that country remains a major importer of raw materials and processed primary commodities while exporting mainly manufactured goods. This trend is also evident in Japan's trade with Canada and Mexico. Trade between Canada and Mexico is also observed to be characterised by low levels of IIT.

Table 8

IIT by Major Trading Partners, 1980-1998*

(Unadjusted Grubel-Lloyd indices, 3-digit SITC level) 


\begin{tabular}{lcccccccc} 
& \multicolumn{2}{c}{1980} & \multicolumn{2}{c}{1990} & \multicolumn{2}{c}{1995} & \multicolumn{1}{c}{$\mathbf{1 9 9 8}$} \\
SITC & $\mathbf{0 - 8}$ & $\mathbf{5 - 8}$ & $\mathbf{0 - 8}$ & $\mathbf{5 - 8}$ & $\mathbf{0 - 8}$ & $\mathbf{5 - 8}$ & $\mathbf{0 - 8}$ & $\mathbf{5 - 8}$ \\
us & & & & & & & & \\
Canada & 0.56 & 0.66 & 0.62 & 0.68 & 0.65 & 0.71 & 0.67 & 0.72 \\
Mexico & 0.26 & 0.36 & 0.60 & 0.73 & 0.56 & 0.64 & 0.56 & 0.61 \\
EU & 0.47 & 0.59 & 0.56 & 0.62 & 0.62 & 0.68 & 0.62 & 0.66 \\
Japan & 0.22 & 0.26 & 0.29 & 0.32 & 0.35 & 0.38 & 0.37 & 0.39 \\
World & 0.45 & 0.62 & 0.62 & 0.69 & 0.66 & 0.71 & 0.66 & 0.70 \\
CANADA & & & & & & & & \\
US & 0.56 & 0.66 & 0.62 & 0.68 & 0.65 & 0.71 & 0.67 & 0.72 \\
Mexico & 0.14 & 0.19 & 0.21 & 0.24 & 0.18 & 0.21 & 0.16 & 0.17 \\
EU & 0.25 & 0.38 & 0.32 & 0.45 & 0.34 & 0.45 & 0.37 & 0.44 \\
Japan & 0.06 & 0.11 & 0.06 & 0.08 & 0.08 & 0.12 & 0.08 & 0.11 \\
World & 0.53 & 0.61 & 0.64 & 0.69 & 0.64 & 0.70 & 0.67 & 0.72 \\
MEXICO & & & & & & & & \\
US & 0.26 & 0.36 & 0.60 & 0.73 & 0.56 & 0.64 & 0.56 & 0.61 \\
Canada & 0.14 & 0.19 & 0.21 & 0.24 & 0.18 & 0.21 & 0.16 & 0.17 \\
EU & 0.09 & 0.12 & 0.18 & 0.26 & 0.36 & 0.41 & 0.34 & 0.36 \\
Japan & 0.04 & 0.05 & 0.06 & 0.11 & 0.09 & 0.10 & 0.06 & 0.06 \\
World & 0.27 & 0.36 & 0.44 & 0.56 & 0.58 & 0.65 & 0.61 & 0.66
\end{tabular}

* EU here refers to the group of 12 members

Source: United Nations Trade Data, International Economic Data Base, Australian National University; authors' own calculations

While the results shed some light on these issues of adjustment, we have shown in Section 2 that inferences from static IIT measures on adjustment might be misplaced. Table 9 therefore reports aggregate measures of MIIT, calculated with the $A$ index.

Looking at trade in manufactured products (SITC 5-8), we find that MIIT, like IIT, displays a generally increasing tendency. Both the US and Mexico show dramatic rises in the A index from the period of the mid-1980's. Table 10 shows that the upward trend in MIIT applies to US trade with Canada, Mexico and the EU, but not Japan.9 Interestingly, trade between the US and Japan is constantly marked by low MIIT and a decline over the 1990's. This aspect of MIIT development would seem to warrant further investigation, suggesting as it does the re-emergence of more sectorally concentrated export and import growth. In the case of Canada, increasing MIIT is seen only in its trade relationship with the US. Mexico shows a strong rise in MIIT with the US and a more modest increase with the EU. In the late 1990's, US MIIT has been almost as high in trade with Mexico (0.52) as in trade with Canada (0.58). Judged by this measure, therefore, recent US trade expansion with Mexico has been similarly balanced at sector level as US trade expansion with Canada, and associated adjustment costs might also have been of comparable relative magnitude.

These results support the notion that the composition of US trade with Canada, Mexico and the EU has been changing in a way that would seem to suggest decreasing inter-industry adjustment pressures. Our MIIT measures 
also resemble our findings on IIT in broad terms although the latter are seen to overstate the extent of two-way trade when compared to the dynamic measure.

Table 9

Total MIIT, 1980-98

(A indices, 3-digit SITC level)

\begin{tabular}{lllllllll} 
& \multicolumn{1}{c}{$\mathbf{1 9 8 0 - 8 5}$} & \multicolumn{2}{c}{$\mathbf{1 9 8 5 - 9 0}$} & \multicolumn{1}{c}{$\mathbf{1 9 9 0 - 9 5}$} & \multicolumn{2}{c}{$\mathbf{1 9 9 5 - 9 8}$} \\
SITC & $\mathbf{0 - 8}$ & $\mathbf{5 - 8}$ & $\mathbf{0 - 8}$ & $\mathbf{5 - 8}$ & $\mathbf{0 - 8}$ & $\mathbf{5 - 8}$ & $\mathbf{0 - 8}$ & $\mathbf{5 - 8}$ \\
US & 0.12 & 0.13 & 0.56 & 0.63 & 0.62 & 0.69 & 0.43 & 0.48 \\
Canada & 0.42 & 0.58 & 0.46 & 0.54 & 0.51 & 0.61 & 0.52 & 0.60 \\
Mexico & 0.14 & 0.16 & 0.35 & 0.54 & 0.52 & 0.57 & 0.55 & 0.59
\end{tabular}

Source: United Nations Trade Data, International Economic Data Base, Australian National University; authors' own calculations

Table 10

MIIT of NAFTA Members by Major Trading Partners, 1980-98*

( $A$ indices, 3digit SITC level)

\begin{tabular}{lccccccccc} 
& \multicolumn{1}{c}{$\mathbf{1 9 8 0 - 8 5}$} & \multicolumn{2}{c}{$\mathbf{1 9 8 5 - 9 0}$} & \multicolumn{2}{c}{$\mathbf{1 9 9 0 - 9 5}$} & \multicolumn{1}{c}{$\mathbf{1 9 9 5 - 9 8}$} \\
SITC & $\mathbf{0 - 8}$ & $\mathbf{5 - 8}$ & $\mathbf{0 - 8}$ & $\mathbf{5 - 8}$ & $\mathbf{0 - 8}$ & $\mathbf{5 - 8}$ & $\mathbf{0 - 8}$ & $\mathbf{5 - 8}$ \\
US & & & & & & & & \\
Canada & 0.35 & 0.42 & 0.38 & 0.42 & 0.59 & 0.66 & 0.58 & 0.64 \\
Mexico & 0.13 & 0.17 & 0.51 & 0.68 & 0.40 & 0.43 & 0.52 & 0.56 \\
EU & 0.07 & 0.07 & 0.43 & 0.49 & 0.44 & 0.48 & 0.46 & 0.51 \\
Japan & 0.05 & 0.06 & 0.27 & 0.33 & 0.21 & 0.23 & 0.13 & 0.15 \\
World & $\mathbf{0 . 1 2}$ & $\mathbf{0 . 1 3}$ & $\mathbf{0 . 5 6}$ & $\mathbf{0 . 6 3}$ & $\mathbf{0 . 6 2}$ & $\mathbf{0 . 6 9}$ & $\mathbf{0 . 4 3}$ & $\mathbf{0 . 4 8}$ \\
CANADA & & & & & & & & \\
US & 0.35 & 0.42 & 0.38 & 0.42 & 0.59 & 0.66 & 0.58 & 0.64 \\
Mexico & 0.06 & 0.06 & 0.11 & 0.17 & 0.13 & 0.15 & 0.09 & 0.10 \\
EU & 0.06 & 0.11 & 0.28 & 0.43 & 0.12 & 0.17 & 0.14 & 0.19 \\
Japan & $\mathbf{0 . 0 2}$ & $\mathbf{0 . 0 3}$ & $\mathbf{0 . 0 6}$ & $\mathbf{0 . 0 7}$ & $\mathbf{0 . 0 4}$ & $\mathbf{0 . 0 6}$ & $\mathbf{0 . 0 4}$ & $\mathbf{0 . 0 6}$ \\
World & 0.42 & 0.58 & 0.46 & 0.54 & 0.51 & 0.61 & 0.52 & 0.60 \\
MEXICO & & & & & & & & \\
US & 0.13 & 0.17 & 0.51 & 0.68 & 0.40 & 0.43 & 0.52 & 0.56 \\
Canada & 0.06 & 0.06 & 0.11 & 0.17 & .13 & 0.15 & 0.09 & 0.10 \\
EU & $\mathbf{0 . 0 6}$ & $\mathbf{0 . 0 7}$ & $\mathbf{0 . 1 2}$ & $\mathbf{0 . 2 1}$ & $\mathbf{0 . 1 9}$ & $\mathbf{0 . 3 1}$ & $\mathbf{0 . 2 5}$ & $\mathbf{0 . 2 7}$ \\
Japan & 0.02 & 0.03 & 0.03 & 0.06 & 0.06 & 0.09 & 0.06 & 0.08 \\
World & 0.14 & 0.16 & 0.35 & 0.54 & 0.52 & 0.57 & 0.55 & 0.59
\end{tabular}

* EU here refers to the group of 12 members

Source: United Nations Trade Data, International Economic Data Base,

Australian National University; authors' own calculations

An important feature of the results is the fact that trade between the US and Mexico is seen as more sectorally balanced than many critics would suggest. This suggests that many fears regarding the accession of Mexico into the free trade agreement with the US in respect of labour market impacts are likely to be unfounded. Similarly trade between the US and Canada is 
increasingly two-way in nature. The Canada-Mexico relationship, however, is one which reflects strong growth in trade based on comparative advantage. Primary products and industrial goods dominate Canadian exports, while imports are mainly in the areas of automotive products and machinery and equipment. While Canada does not have the advantage of a common border with the US, proposed liberalisation of road transport between all NAFTA members could work to encourage greater opportunities for two-way trade. Canadian investment in Mexico tends to be concentrated in mining, banking and telecommunications. Since the mid-1990's Canada has tended to focus its investments in the US. In contrast, the US has invested relatively more in manufacturing in Mexico than has Canada.

\section{CONCLUSIONS}

This study addresses the question of labour market adjustment in the face of the expansion of trade in NAFTA economies. Particular emphasis is placed on the period 1990-1998, a time-frame which spans several years both prior to and after the establishment of the NAFTA agreement. The trade patterns of member countries of NAFTA are analysed.

Traditional trade theory with its attention to inter-industry trade focuses on the structural change and distributional impacts of increased trade where there are both winners and losers within trading nations. This paper develops the proposition that trade expansion which is more IIT in nature will entail relatively lower labour market adjustment costs (the so-called smooth adjustment hypothesis).

A measure of marginal IIT is expounded alongside the traditional static GL index and it is argued to be negatively related to adjustment costs. Results presented here suggest that despite the lower level of Mexico's economic development relative to its more industrialised partners in NAFTA, static IIT for each country has grown steadily over the period of the study, particularly in manufacturing goods. A similar trend is seen in the case of MIIT, where US-Mexican trade expansion is now almost as sectorally balanced as US-Canada trade.

In looking at trade of each NAFTA member with its major trading partners, some differences in the extent of two-way trade flows are evident. US trade with Canada, Mexico and the EU show an upward trend in MIIT, whereas it exhibits a relatively low and declining level with Japan. For Canada, increased MIIT is observed only in its trade with the US. In particular, trade with Mexico is still seen to be primarily inter-industry in nature. Mexico shows a high and growing MIIT with the US while a more modest trend is evident for trade with the EU. MIIT remains low with Japan and Canada.

The changing structure and composition of trade flows of NAFTA members suggest that within NAFTA less labour market adjustment pressures are being experienced by the US and Mexico in terms of their trade relationship than is suggested by some critics of trade liberalisation. A similar observation can be made for US-Canada trade. Relative to its (much smaller) volume, however, trade expansion between Canada and Mexico, however, likely gives rise to greater factor-market adjustment pressures. 


\section{REFERENCES}

Balassa, Bela (1966) "Tariff Reductions and Trade in Manufactures among the Industrial Countries". American Economic Review, vol. 56, pp. 466473.

Baldwin, Robert E., Mutti, John H. and Richardson, J. David (1980) "Welfare Effects on the United States of a Significant Multilateral Tariff Reduction". Journal of International Economics, vol. 36, pp. 405-23.

Brecher, Richard A. and Choudhri, Ehsan U. (1994) "Pareto Gains from Trade Reconsidered: Compensating for Jobs Lost". Journal of International Economics, vol. 36, pp. 223-238.

Brülhart, Marius and Thorpe, Michael (1999) "East Asian Export Growth, Intra-Industry Trade and Adjustment". Asia Pacific Journal of Economics and Business, vol 3, pp. 34-46.

Brülhart, Marius and Hine, Robert C. (1998) (eds), Intra-Industry Trade and Adjustment:The European Experience, MacMillan, London

Brülhart, Marius (1994) "Marginal Intra-Industry Trade: Measurement and Relevance for the Pattern of Industrial Adjustment". Weltwirtschaftliches Archiv, vol. 130, pp. 600-613.

Brülhart, Marius; (2000) "Intra-Industry Trade and Labour Re-allocation: A Firm-Level Panel Study". mimeo, Trinity College Dublin.

Burfisher, M. E., Robinson, Sherman and Thierfielder, K. (2001) "The Impact of NAFTA on the United States". Journal of Economic Perspectives, vol. 15, pp. 125-144.

Cremeans, J. (1999) Handbook of North American Industry. Bernan Press, Washington DC

Dixit, Avinash and Norman, Victor (1986) "Gains from Trade without LumpSum Compensation”. Journal of International Economics, vol. 21, pp. 111-122.

Feenstra, Robert C. and Lewis, Tracy R. (1994) "Trade Adjustment Assistance and Pareto Gains from Trade". Journal of International Economics, vol. 36, pp. 201-222.

Fontagné, Lionel; Freudenberg, Michael and Péridy, Nicolas (1997) “Trade Patterns Inside the Single Market”. Document de travail, no. 97-07, CEPII, Paris.

Freeman, Richard B. (1995) “Are Your Wages Set in Beijing?" Journal of Economic Perspectives, vol. 9, pp. 15-32.

Gonzalez, Jorge G., and Velez Alejandro (1995) "Intra-Industry Trade between the United States and the Major Latin American Countries: Measurement and Implications for Free Trade in the Americas, The International Trade Journal, vol ix, pp. 519-536

Greenaway, David; Hine, Robert C. and Milner, Chris (1994) "Vertical and Horizontal Intra-Industry Trade: Some Cross-Sectional Evidence for the UK”. Economic Journal, vol. 105, pp. 1505-1518.

Greenaway, David and Milner, Chris (1986) The Economics of Intra-Industry Trade. Oxford, Basil Blackwell.

Hamilton, Clive and Kniest, Paul (1991) "Trade Liberalisation, Structural Adjustment and Intra-Industry Trade: A Note". Weltwirtschaftliches Archiv, vol. 127, pp. 356- 367. 
Hunter T. (1998) The Impact of FTA/NAFTA on Canada: What does the Recent Literature Say? Department of Foreign Affairs and International Trade, Trade and Economic Analysis Division, Canadian Government

Krugman, P. (1995) "Growing World Trade: Causes and Consequences". Brookings Papers on Economic Activity, pp. 327-377

Lustig, N. (2001) "Life is Not Easy: Mexico's Quest for Stability and Growth". Journal of Economic Perspectives, vol. 15, pp. 85-106

McClenahen J. S. (2000) "NAFTA Works" Industry Week”. Industry Week, Cleveland, January 10

Menon, Jayant and Dixon, Peter B. (1997) "Intra-Industry versus InterIndustry Trade: Relevance for Adjustment Costs". Weltwirtschaftliches Archiv, vol. 133, pp. 164-169.

Neary, J. Peter (1985) "Theory and Policy of Adjustment in an Open Economy". In: Greenaway, D. (ed.) Current Issues in International Trade, Macmillan, London.

Ojeda R. H. et al (1996) North American Integration Three Years after NAFTA, North American Integration and Development Center, University of California, Los Angeles

Oliveras, Joaquín and Terra, Inés (1997) "Marginal Intra-lndustry Trade Index: The Period and Aggregation Choice". Weltwirtschaftliches Archiv, vol. 133., pp. 170-179.

Sachs, Jeffrey D. and Shatz, Howard J. (1996) "U.S. Trade with Developing Countries and Wage Inequality". American Economic Review (Papers and Proceedings), vol. 86, pp. 234-239.

Scheve, Kenneth F. and Slaughter, Matthew J. (2001) Globalisation and the Perception of American Workers. Institute for International Economics, Washington, DC.

Slaughter, M J. and Swagel, P. (1997) "The Effects of Globalisation on Wages in the Advanced Economies". IMF Working Paper, 9473, April.

US International Trade Commission (1997) US Trade with Mexico during the Third NAFTA Year, Washington

Weintraub, S (1997) NAFTA at Three: A Progress Report. The Center for Strategic and International Studies, Washington, DC.

Wood, Adrian (1994) North-South Trade, Employment and Inequality. Clarendon Press, Oxford.

Wood, Adrian (1995) "How Trade Hurt Unskilled Workers". Journal of Economic Perspectives, vol. 9, pp. 57-80. 


\section{ENDNOTES}

\footnotetext{
${ }^{1}$ NAFTA was established in 1994. Member countries are the United States, Canada and Mexico. The agreement extends the 1989 Canada-United States Free Trade Agreement (CUSFTA).

${ }^{2}$ Real economies, of course, are subject to continuous changes in demand and production structures. Therefore, integration occurs simultaneously with other changes, and the two types of trade-induced adjustment, while separable in theory, are difficult to disentangle empirically.

${ }^{3}$ see Baldwin, Mutti and Richardson. (1980, p. 408).

${ }^{4}$ see Feenstra and Lewis (1994, p. 202). Dixit and Norman (1986) have proposed an incentive-compatible taxation scheme which ensures Pareto gains.

${ }_{5}$ see Baldwin Mutti and Richardson (1980, p. 408ff.). Brecher and Choudhri (1994) have formalised this proposition in an efficiency-wage model.

${ }^{6}$ Hamilton and Kniest (1991), Greenaway et al. (1994) and Menon and Dixon (1997) have proposed alternative measures of MIIT.

${ }^{7}$ Oliveras and Terra (1996) have shown that the statistical properties of the $A$ index differ from those of the GL index in two respects. First, the $A$ index is not subject to an growing downward bias as the level of statistical disaggregation is increased. Second, there is no functional relationship between the $A$ index for a certain period and the $A$ indices of constituent subperiods.

${ }^{8}$ Cremeans (1999) notes that the trade liberalisation under the NAFTA agreement has been only one factor in the trade equation since 1994. Also important have been shifts in relative exchange rates and relative inflation rates. Moreover the import growth into the US is considered to have eased strains on domestic production and helped curb inflationary pressures. ${ }^{9}$ Brülhart and Thorpe (1999) show that US trade with Malaysia and the Philippines, but not with Indonesia and Korea, was characterised by a high and rising trend in MIIT over 1990-1996.
} 